\title{
Task-Based Language Learning and Beginning Language Learners: Examining Classroom-Based Small Group Learning in Grade 1 French Immersion
}

\author{
Renée Bourgoin \\ St. Thomas University \\ Josée Le Bouthillier \\ University of New Brunswick
}

\begin{abstract}
Elementary French immersion (FI) language arts teachers often organize instruction around small learning groups. Students rotate through learning stations/centres and work independently with their peers on L2 literacy skills. This study examined how principles of task-based language teaching (TBLT) can be used and/or adapted to further support beginning L2 learners working independently at various literacy stations. This classroombased study employed a pragmatic 'research design' methodology. Researchers worked alongside Grade 1 FI teachers $(n=3)$ in the development and classroom implementation of language/literacy tasks designed around TBLT principles for use in literacy centres. Data collected included classroom observations in two Grade 1 FI classrooms, samples of students' work, teacher interviews, and task-based lesson plans. Findings suggest that integrating/adapting TBLT principles to small group independent learning stations was particularly impactful in supporting young beginning language learners with extended language output, peer interaction, learner autonomy, emerging spontaneous language use, and student engagement. Additional instructional focus on corrective feedback, oral communication skills, and focus on form and function were also reported.
\end{abstract}

\section{Résumé}

L'enseignement des arts langagiers dans les programmes d'immersion française (IF) est souvent organisé de façon ou les élèves travaillent en petits groupes appelés centres de littératie. Dans ce schéma organisationnel, les élèves vont de centre a centre afin de travailler des habiletés langagières avec leurs pairs. Cette étude examine comment certains principes de l'apprentissage basé sur les tâches (ABT) peuvent être utilisés and/ou adaptés afin de soutenir davantage de jeunes élèves dans les premières phases d'acquisition d'une langue seconde (L2) lorsqu'ils travaillent à divers centres de littératie en classe. Cette recherche emploie une méthode de recherche qui est pragmatique et encrée dans la pratique et a vu les chercheuses travailler étroitement avec trois enseignants $(n=3)$ de la $1^{\text {ere }}$ année au développement et à la mise en œuvre de tâches langagières conçues avec les principes sousadjacents de l'ABT. Ces tâches ont été effectuées indépendamment par les élèves aux diffèrent centres d'apprentissage. Les résultats d'observations de classe, d'entrevues avec les enseignants et de travaux des élèves démontent qu'il soit possible d'intégrer/adapter les principes de l'ABT dans des contextes d'apprentissage ou de jeunes enfants, débutant dans la L2, travaillent indépendamment à des tâches de littératie et que, ceux-ci sont particulièrement percutants pour soutenir l'usage étendu et spontané de la L2, les interactions 
entre pairs, l'autonomie des apprenants et l'engagement/motivation. L'usage de la rétroaction corrective et une réorientation vers l'enseignement de la forme et fonction de la langue ont aussi été constatée.

\section{Task-Based Language Learning and Beginning Language Learners: Examining Classroom-Based Small Group Learning in Grade 1 French Immersion}

\section{Introduction and Research Context}

Students enrolled in early French immersion (FI) learn the majority of their subjects in French including learning fundamental literacy skills in French in their language arts classes. The term literacy, which traditionally has been associated with reading and writing particularly in schooling contexts, has in more recent years been expanded to include additional dimensions of language learning. There has been a reorientation toward oral language, interactions and socialization, and developing critical perspectives in addition to the development of various pre-reading/reading and written communication skills. As is explained by Ontario's Ministry of Education (2013) "literacy is the ability to use language and images in rich and varied forms to read, write, listen, speak, view, represent, discuss and think critically about ideas...[and] enables us to share information and to interact with others" (p. 3). This broader view of literacy instruction encompasses the notion that, through literacy, students can "engage with language to acquire, construct and communicate meaning in all aspects of daily living" (Alberta Education, 2015). Literacy is the act of creating and constructing meaning with language (Kucer, 2015) and is engrained in social practice (Street \& Lefstein, 2007).

FI programs often borrow teaching pedagogies and frameworks designed for first language (L1) students (Canadian Association of Immersion Professionals, 2018). The use of literacy learning centres is one such framework derived from the L1 context. In L1 and L2 elementary language arts classes, literacy centres or stations are a widely used pedagogical framework for literacy instruction. Within a given literacy lesson, students organized in small groups - rotate through different learning stations and work independently or with their peers on literacy-related tasks. According to Diller (2005), centres are a way of allowing students to use learning materials to explore and expand upon their literacy skills. Time spent working at various literacy centres should allow students to practice reading, writing, oral, and listening skills, as well as vocabulary (Diller, 2010). By using literacy centres, teachers are liberated from whole-class instruction, thus allowing targeted instruction for a few students to take place (Kracl, 2012). This targeted instruction usually focuses on supporting the individual needs of readers through guided reading practices (Fountas \& Pinnell, 2017), and in elementary FI, many language-arts classes are designed around this type of small group literacy instruction (see Figure 1). 


\section{Figure 1}

Small Group Literacy Instruction Framework

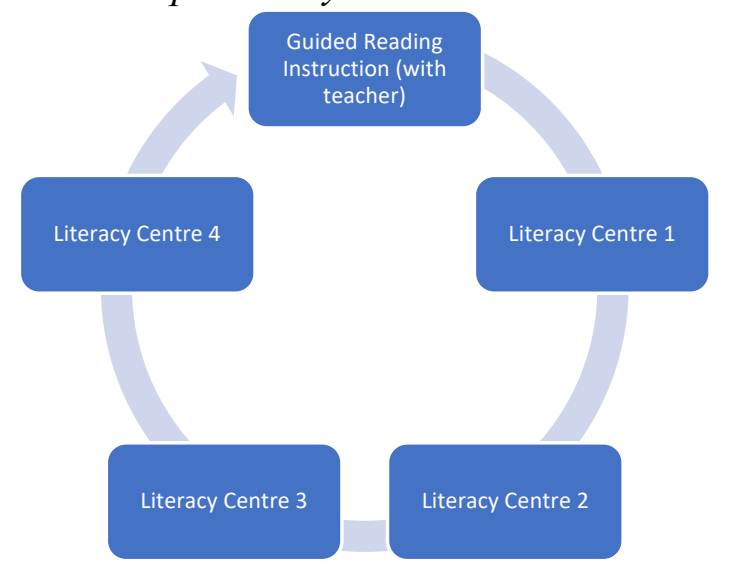

Since the primary role of using this instructional framework is to allow the teacher to work closely with small groups of readers, much of the planning and teaching emphasis has been on providing strong, targeted reading interventions. This has been at the expense of planning for meaningful and engaging tasks at the various literacy stations. The tasks students engage with at these learning stations have been neglected (Ford \& Opitz, 2002). This is particularly problematic since most students generally spend $2 / 3$ of the time working at the literacy centres during language arts classes.

Moreover, studies conducted in L1 contexts found that the work students perform at literacy centres tends to be repetitive and inconsequential, often comprising of worksheets that do not further develop literacy skills. According to Ford and Opitz (2002) and Kracl (2012), literacy centres do not always serve their intended purpose and more work is needed to properly structure them in order to maximize student learning. Along with concerns over the pedagogical value of tasks conducted within literacy centres, there is also a lack of academic literature examining the use of literacy learning centres in L2 classroom learning contexts. This is particularly the case with respect to young, school-age learners in the beginning stages of L2 language acquisition.

Within L2 language learning contexts, the role of oral language for the development of literacy skills (i.e., reading and writing) is well documented (ex. Shanahan, 2016). According to Soucy (2016), oral communication includes social and academic interactions, oral production and comprehension, and the ability to critically interpret messages and participate in exchanges. L1 pedagogical materials referencing literacy centres neglect the development of oral communication skills and limit the focus to reading, writing, listening, and vocabulary tasks (Soucy, 2016). Additionally, since the literacy centres framework was designed for L1 learners, there are no references to specific L2 teaching and learning adaptations needed to support L2 students working independently on learning L2 language/literacy skills at these learning stations. Thus, questions arise about the effectiveness of literacy centres in supporting L2 language and literacy learning and how best to support this popular pedagogical framework for elementary FI students. In this study, we sought to examine the pedagogical principles needed for the development of effective L2 literacy tasks for learning centres. To explore this question, we turned our attention to task-based language teaching literature to help bridge the divide between the 
aforementioned shortcomings of L1 literacy centres and the need to further support L2 acquisition in FI classrooms.

\section{Theoretical Frameworks / Literature Review}

This study was designed to explore how literacy centres, designed, for the most part, to support L1 literacy instruction, could be reconceptualized to support the L2 language/literacy development of young language learners in FI elementary classrooms. A review of the literature was done with respect to two areas of research, that of task-based language teaching and classroom-based learning centres.

\section{Task-Based Language Teaching}

Although definitions vary in terms of what constitutes 'tasks' within the task-based language teaching (TBLT) literature, Long (2014) recommended that they should be defined as real-life activities that people do when planning and carrying out their day. When describing characteristics of TBLT, DeKeyser (2018) underscored that language tasks should focus primarily on meaning, but within these exchanges, students should also be guided toward form. Additionally, students should have opportunities to take ownership of their language learning. For his part, Ellis (2009) has suggested that language tasks should contain information gaps in order for students to engage with each other in more meaningful and spontaneous ways. TBLT should also allow for students to reflect on their own language use and moreover, problem-solve to determine next steps in using the language.

Ellis (2009) and DeKeyser's (2018) conceptualization of TBLT differs somewhat from that of Long (2014) in that, for the former, form and function are more closely connected (Ellis, 2000, 2003, 2017; Skehan, 1998; Nunan, 2006). Within this optic, the teacher's role cannot be ignored in that they are needed to support language fluency and

guide students toward more precise language use. Other studies within the TBLT literature have examined other pedagogical aspects of TBLT including goals of the task, language input, types of tasks, linguistic and cognitive complexity of tasks, procedures involved, interaction/output demands, and planning (Oxford, 2006).

Our review of the literature found little TBLT research conducted with young elementary L2 school-aged children. TBLT research seems to be more established with older groups of high school and university level students (Newton \& Bui, 2018). The few studies conducted with primary students yielded somewhat contradictory findings. On the one hand, Carless (2004), Kim (2013), and Lee (2005) found that TBLT interactions among school-aged L2 children were limited, that a few students tended to monopolize discussions, and that most students produced very little language output with utterances remaining at the one-word level. Additionally, it was reported that most did not seem to engage in meaning-making interactions, focused very little on form, and employed the L1 too frequently, limiting the possibilities of extended output. In light of these findings, researchers recommended that the need to focus more closely on the types of tasks proposed to young language learners. Contrarily, the Newton \& Bui (2018) study reported more encouraging findings with respect to TBLT with younger language learners, documenting high student engagement, evidence of extended language output, and use of 
meaning-making strategies. They attributed these findings to teachers' openness toward implementing TBLT principles into their teaching pedagogy.

Additional TBLT research in this area is needed with respect to younger language learners, particularly within real-life L2 learning contexts. As Shehadeh (2012) postulated, it is important to study TBLT in classroom contexts rather than laboratories. The definition of literacy aforementioned describes it as a social practice that encourages understanding of the people around us and fosters interactions with others with respect to all aspects of daily life. Since our study was conducted with L2 elementary school-aged children, we favour real-life tasks to language learning, but understand that in FI contexts, students are learning the L2 within a formal education setting. Consequentially, we adopted arguably the most popular theoretical perspective within L2 schooling contexts for this study, that of emphasizing tasks that focus on function and meaning-making while also providing students with an opportunity to practice specific language features (DeKeyser, 2018). Given the age of the students, authentic real-life activities/tasks for young elementary students can include symbolic play, inquiries and social interactions that help them learn about the world they live in and its' surroundings, and also participating in classroom learning activities designed to help them learn how to read, write and communicate.

\section{Classroom-Based Learning Centres}

Classrooms often used learning centres/stations as a way for students to engage with the material and help them consolidate their learning of newly acquired concepts and skills. With respect to their use in literacy/language arts classes, although widely used in elementary contexts, academic literature on their effectiveness remains limited. Findings reported by Stout (2009) included increased teaching effectiveness and student focus when using learning centres. These findings were attributed to the use of specific learning outcomes and offering student choice when planning and carrying out centre work. Literacy centres that allowed students to take a more active role in their learning and that included collaborative brainstorming activities and collaborative writing tasks were found to encourage more student ownership of their learning and favoured learning (Falk-Rose, 2008; Kracl, 2012). Worthy et al. (2015), who explored teacher perceptions of literacy centres, found that although teachers believed they were designing pedagogical sounds learning stations, tasks remained repetitive and inconsequential. Findings reported elsewhere (ex: Cambourne, 2001; Kracl, 2012; Reutzel \& Clark, 2011) also mention the need for social interactions and cognitive collaboration, the use of various aspects of the language, the transfer of learning to new contexts, considerations for different ability levels, and the use of open and creative answers in supporting learning within this instructional framework.

\section{Research Problem}

Literacy centres were first conceptualized to support L1 literacy instruction by offering students opportunities to work independently on literacy-related skills, mostly linked to reading and writing. This organization framework has since been adopted in elementary FI classes with little consideration given to the unique needs of L2 learning environments and young L2 learners. However, little attention is given to the development 
of oral communication skills in L1 contexts (Soucy, 2016). Considering the amount of time young L2 students spend working independently at these learning stations, questions remain about the extent to which students actively engage with the L2 at these independent learning stations and the types of tasks needed to foster L2 literacy/language learning, rather than them being repetitive and inconsequential. As such, this study set out to explore how literacy centres, designed, for the most part, to support L1 literacy instruction, could be reconceptualized to support the L2 language/literacy development of young language learners in FI classrooms.

Our review of the literature revealed that only a limited number of studies have focused on TBLT with younger language learners and thus, examining the application of task-based principles within elementary schooling contexts warrants important consideration in the area of TBLT research. Since many L2 language-arts classes already use learning centres to support instruction, literacy centres create an interesting context to study TBLT principles in action with young beginning language learners. Given the findings of Carless (2004), Kim (2013), and Lee (2005) showing limited success of TBLT with younger learners, coupled with recommendations for a further examination of the types of tasks proposed to such learners, we set out to explore how TBLT principles could be applied and/or adapted to existing literacy centres in hopes of enhancing the pedagogical merit of these small group independent learning centres for L2 learning.

\section{Research Questions}

Given the amount of time that FI students spend working independently at various literacy stations in language arts classes, in addition to the need to ensure that literacy centres serve the intended purpose of maximizing students' learning (Ford \& Opitz, 2002; Kracl, 2012), we turned our attention to investigating aspects of TBLT in the context of elementary FI classrooms. The following questions guided our study:

1. How can TBLT principles be adapted to support young beginning language learners?

2. How do these tasks, co-constructed with teachers, favour language/literacy acquisition and extended language/literacy learning for young beginning language learners?

3. What instructional structures and strategies are needed to effectively implement/adapt TBLT principles in classrooms where beginning L2 students are expected to work independently on second language/literacy skills at small group learning stations?

\section{Methodology}

This study is part of a larger qualitative study (Bourgoin \& Le Bouthillier, 2021) ascribing to a research paradigm in education of developing pedagogical materials, strategies, methods, models or programs that affects pedagogical practice (Loiselle \& Harvey, 2007). More specifically, we adopted a 'research design' methodology (Brown, 1992) that is pragmatic in nature (Cobb et al. 2003) and product-oriented, although 
theorizing within actual classroom contexts remains an important element of this research design (Barab \& Squire, 2004).

We were interested in exploring qualitatively (Kemmis \& McTaggart, 2005) the intersect between TBLT principles and literacy centres in L2 classrooms for beginning language learners in early FI. During the initial phase of this study, professional learning opportunities were offered by researchers to teacher participants to identify ways by which TBLT principles could be applied and/or adapted for beginning language learners working independently at various learning stations. Specific TBLT principles examined were: (1) the need for real-life activities, (2) a focus on meaning without neglecting form, (3) student ownership, (4) attention to the information gap, (5) reflection on learning, (6) teacher's role within this framework, and (7) problem-solve to determine next steps in language use.

Secondly, teachers worked alongside researchers to create language/literacy tasks to be implemented in their literacy centres. The underpinnings of TBLT served as anchors for the co-creation of tasks performed within L2 literacy centres and language learning, although special considerations for the application of TLBT principles were needed to account for the following factors: students' age (6-year-olds), their oral language abilities (beginning stages of L2 acquisition), and the fact that tasks were to be conducted in a classroom setting without the support of the teacher (i.e., rotating through literacy centres). In line with recommendations for the need to focus more closely on the types of tasks proposed to young language learners (Carless, 2004; Kim, 2013; Lee, 2005), attention was also placed on supporting extended language output, meaning-making interactions, and limiting L1 output. Teacher involvement was deemed essential in these two phases considering the findings of Newton \& Bui (2018) that teachers' openness to implementing TBLT principles led to higher student engagement, more extended language output, and use of meaning-making strategies. The following are a few examples of language/literacy centre tasks co-created with these principles and factors in mind:

1. Roleplay centre: At this station, students were presented with some type of roleplay situation (i.e., ordering pizza at a local pizzeria) and tasked with interacting with each other with respect for the roleplay scenario. In this case, students ordered pizzas while others confirmed orders, and drew or write down the orders (see Figure 2). Other similar oral roleplay centres included reporting a lost pet at a police station, shopping for groceries, and buying animals at a pet shop.

\section{Figure 2}

\section{Pizzeria Roleplay Centre}

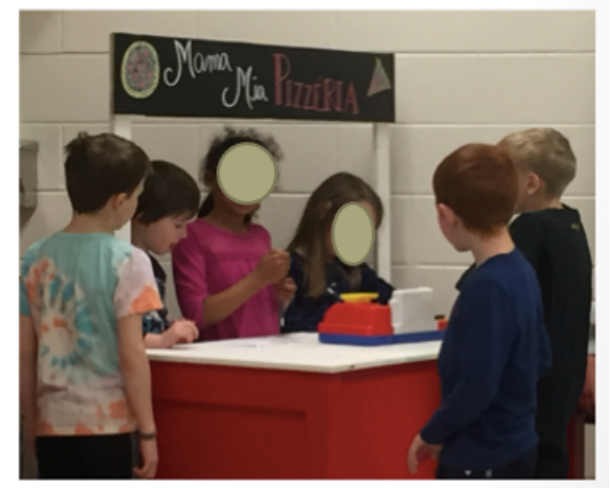


2. Writing centre: At this station, students read a short book, each page containing a short description of a person. After reading the text, students were tasked with becoming authors who needed to add an additional page to the book using the existing book pages as exemplars, along with other exemplars created by the teacher (Figure 3). Students then discussed their page with others at the centre. Initially designed as a writing task, it was reconfigured to add elements of oral communication for better alignment with a need for communicative exchanges where students engage with each other in meaningful ways (Ellis, 2009).

Figure 3

Writing Centre

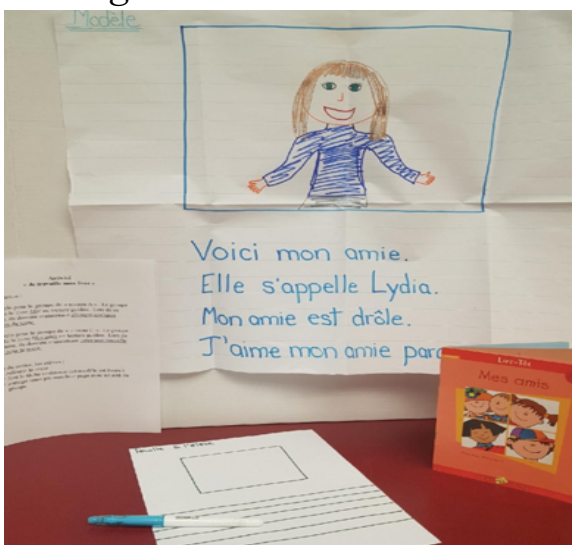

3. Picture description centre: At this station, students were provided with pictures, drawings or photographs depicting themes studied in class (ex: a plate of food, a classroom scene, a photo of a house). Students described the pictures to others at the learning centre. To document their learning, students took notes of the content of others' descriptions.

In all these examples, students' learning artifacts (i.e., drawings/written, book pages, audio recording, check-marked pictures, worksheet) were intended as a way for students to take more ownership of their learning while completing the task. They were also used by the teacher as a comprehension check and later reinvested in whole group learning contexts as a way to help students discuss, reflect upon their learning, and help them identify next steps/goals for their language learning.

As a final step to the research design, co-constructed tasks were integrated into classroom practice within the literacy centre framework. As such, researchers were able to conduct classroom observations to document the processes involved in and results of implementing TBLT principles in literacy centres in authentic academic language-learning settings (i.e., early FI classes)

\section{Participants, Data Collection \& Analysis}

Data were collected with beginning L2 students $(N=37)$ from two urban Grade $1 \mathrm{FI}$ classes. Students had done their Kindergarten year in English and had transitioned to a total early FI program in Grade 1 where they spent approximately $90 \%$ of their day 
immersed in French. Both classes were taught by teachers with 5-10 years of teaching experience. Data were collected in the spring, over a two-month period (April-May), after students had been in the FI program for eight months.

Data collected included teacher-researcher constructed tasks (lesson plans/guides), field notes taken during professional learning sessions, samples of students' work. Three teacher $(N=3)$ interviews were conducted, two with the classroom teachers and one with the literacy coach supporting these two classrooms. All teacher interviews were audiorecorded and transcribed. Additionally, researchers conducted classroom observations of Grade 1 language arts classes (two visits in one class and three visits in the other) during the 8-week data collection period. During each visit, researchers/research assistants observed three different groups of students rotating through each of the learning centres. Centres with a heavier focus on oral communication skills were video and audio recorded. Observational field notes and pictures of literacy centres were taken. Classroom video footage and recorded interviews were transcribed and analyzed based on specific taskbased criteria through qualitative coding techniques. Various data sets, including classroom observational data, teacher interviews, students' work, and task descriptions were used to triangulate the data. Data were analyzed by examining the applications of key principles of TBLT as they applied to independent learning literacy centres used in elementary FI classrooms.

\section{Findings}

By designing literacy centre tasks using principles of TBLT and documenting their use in Grade 1 FI classrooms, we were able to study the ways by which these principles can serve to support the development of L2 literacy skills (oral communication, listening, reading, and writing) and document instructional structures and strategies needed to implement task-based language/literacy learning centres that are pedagogically valuable for beginning language learners. These findings shed light into how TBLT principles such as the need for real-life activities, a focus on meaning without neglecting form, student ownership, attention to the information gap, reflection on learning, teacher's role, and language problem-solving can be applied or adapted to an elementary schooling context with 6-year-old students to support L2 learning.

\section{Increased Focus on Oral Communication Skills Related to Form and Function}

Data revealed that prior to researchers working with teachers on integrating TBLT principles within their literacy centres, the work Grade 1 FI students were expected to complete was, for the most part, unstructured and lacked focus. Similar to the findings of Ford \& Opitz (2002), we found that the tasks students engaged with as they rotated through the different centres were repetitive and inconsequential. As one teacher explained, "I think we still have it in our heads that centres are just 'busy work', things like worksheets or 'cut this, glue that' activities, but it's true...students have thirty minutes to complete an activity, why not have them talk and communicate in French during this time" (Cara, teacher interview). Moreover, centres lacked specific language or literacy outcomes/goals and

tended to be associated with more traditional L1 literacy abilities (reading and writing). For example, students were expected to simply 'write' at the writing centre, 'read' at the 
reading centre, or 'listen' at the listening centre (classroom observations). The notion of creating tasks specifically targeting language or literacy learning outcomes had been neglected. During professional learning sessions with teachers, we shared with them that the acts of listening, reading, writing, or talking, in and of themselves, did not necessarily constitute 'tasks'. By connecting specific listening, oral communication, reading, and writing outcomes to literacy centres, tasks became more focused and targeted to specific literacy expectations and teachers began to think more deeply about integrating specific tasks related to oral communication. As teacher Cara explained, "We realized, after our discussions about the need for some centres to focus on oral communication, that students needed to practice speaking in French [at centres]. Now, everything has changed. It is so important to have oral communication centres" (teacher interview).

Interestingly, the notion of having clearly defined outcomes for literacy centres was amplified when teachers used 'I can' statements to explain tasks expectations to students (e.g., I can describe this image using words I know; I can use connector words such as also, and, because - to add more details; I can use the past tense to describe an event). Through the use of 'I can' statements, we saw the emergence of tasks more focused on function and on form, as the following examples, taken from classroom video recording data, illustrate.

Example 1: For this task, students had to roleplay being in a grocery store. The teacher provided the following 'I can' statements to students: I can welcome and serve a person politely and I can name food items.

$\begin{array}{ll}\text { Bella } & \begin{array}{l}\text { Bonjour, bienvenue à Épicerie Davis. } \\ \text { Sam }\end{array} \\ & \begin{array}{l}\text { Bonjour, j'ai besoin d'acheter beaucoup de nourriture pour la } \\ \text { Bella }\end{array} \\ \text { Sam } & \text { Je peux t'aider. As-tu une liste? } \\ \text { Bella } & \text { Deui a deux listes. Est-ce que je peux a deux crèmes glacées? }\end{array}$

Example 2: For this task, students were expected to provide short descriptions during another roleplay task. The teacher provided the following 'I can' statement to students: I can describe stuffed animals using colours I know.
Ajay
Au secours, au secours!
Henry Je peux t'aider?
Ajay Mon toutou est disparu. Je les a pas vu depuis hier.
Henry Tou a décrire?
Ajay Il a les yeux roses avec un bec qui est rose.
Henry Est-ce que c'est tout?
Ajay De noir dans le milieu. (Silence) Et une bec ... Ça c'est la couleur des yeux c'est vraiment rouge. Tu pourrais juste faire rouge.

With the use of clearly defined learning outcomes using 'I can... statements', students knew the expectations and could work at meeting them. This allowed for students to take more ownership of their learning, work more independently, and were able to measure 
their progress. Literacy centres focusing on oral communicative tasks allowed for more targeted instruction of specific oral language learning outcomes and students' language output increased. As Teacher Missy explained:

I had never planned as much for oral communication tasks before or seen such concrete results... there is no doubt that students' oral production skills were of higher quality...Students love the oral communication centre...they are more engaged at doing the tasks. The centres had more value and the quality of French and learning, in general, increased. (teacher interview)

Teacher Cara described the same thing after integrating additional oral communication learning objectives in her centres. She noted that "After the completion of oral tasks at the centres, students continued to speak in French...the French continued all day. Also, before, students would have probably spoken in English during centres" (teacher interview). Although the two tasks described above focus primarily on meaning, there are also 'I can' statements related to form (DeKeyser, 2018). Within these exchanges evidence, there is also evidence of an information gap whereas enabling students to produce more extended output and engage in meaning-making.

\section{Structuring Tasks with Enough Structure and Flexibility to Foster Extended Oral Output}

During professional learning meetings, teachers doubted whether Grade 1 FI students could produce extended oral output in their L2 at independent learning stations, given their limited language skills and age. They felt that, without a lot of structure, students may resort to employing the L1 too frequently. Much thought was put into designing oral tasks with enough structure to negate the need for teacher support or the L1. Finding the proper balance between providing beginning L2 students with enough structure to successfully complete L 2 communicative tasks independently proved a bit challenging initially, as too much structure seemed to stiffen the information gap needed to foster more spontaneous language use.

For example, the initial design of the oral centre constituted tasking students with describing pictures of familiar themes (ex., describing a plate of food, a classroom, a house) to one another in their small learning groups. However, in an attempt to further scaffold the task and limit the use of the L1, teachers only selected a limited number of pictures for students to describe. The pictures that were provided were selected because they were simple with limited details (see Figure 1). Within a few weeks, however, teachers reported that their students were working through this type of task with too much ease and that engagement was weaning. Professional reflections conducted with teachers revealed the need to adapt tasks to meet students' increasing language capacities. In this case, picture selection needed important consideration, as generic pictures did not provide enough of an information gap for students. Vocabulary was limited to the content of the pictures, which in turn, limited opportunities for extended output (classroom video recordings of oral centres). This reduced the demand to communicate.

The need to ensure the right information gap was necessary for students to continue engaging with the material. To rectify this and account for the increasing L2 language 
skills of Grade 1 FI students, teachers regularly modified and adapted oral language tasks within the two-month data collection period. This was done to push students' oral language skills toward more spontaneous speech, to allow for more creative answers, and to promote the use of extended oral output. Teacher Cara, for example, asked students to bring in their own pictures/photos (see Figure 2).

\section{Figure 4}

\section{Generic Picture provided by the Teacher}

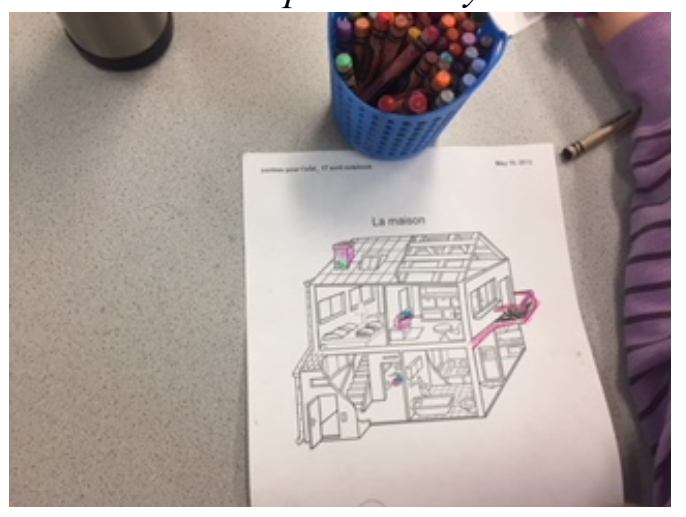

Figure 5

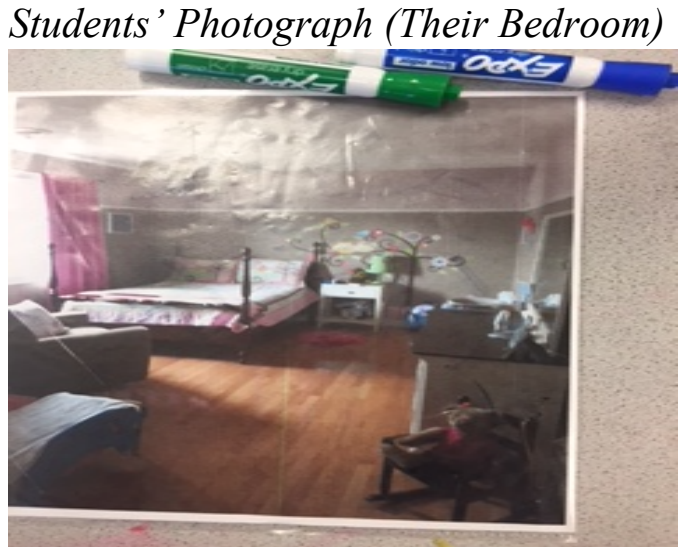

Students' own photographs, connected to their lives and unique experiences, were more motivating to describe and provided the information gap needed to further engage with the material and foster more interactions amongst students in the centre. Although the teacher had less control over the content of the photos, students experimented with the language by using more lexical frames, as this example demonstrates:

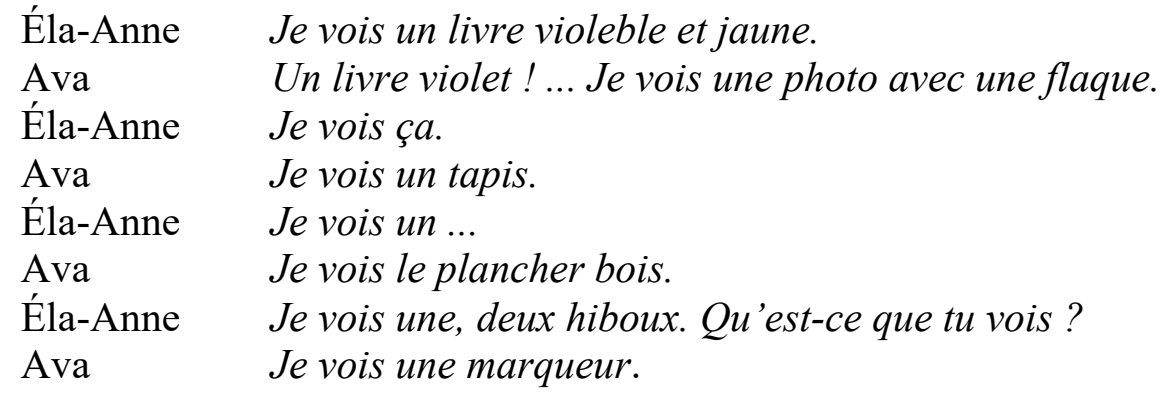



Éla-Anne Une marqueur?
Ava $\quad$ Sous le ... oh, dans euh ... cette tableau blanc marqueur.
Éla-Anne C'est un tableau blanc marqueur.
Ava Je vois un fleur. Je vois un chaise, un chaise bois.
Éla-Anne Je vois un, trois autres fleurs. (classroom video recording)

This exchange highlights the use of various lexical frames related to colours, classroom objects, things in nature, and animals, which would otherwise not have been discussed with the generic picture. Students are producing very few if any, one-word utterances instead choosing to communicate in full sentences in their L2 without any need for the L1. There is also evidence of students negotiating meaning within this exchange

Students were particularly excited to share and describe their personal photos and engagement seemed to increase as a result of real-life connections with the material under study.

Teacher Cara admitted that she had underestimated her students. She realized that the tasks she had created for her students had rapidly become too easy for them (teacher interview). A similar finding was reported at the other research site. The teacher, in that case, also felt the need to rework her oral communication centre by abandoning the task of describing pictures altogether and replacing it with a roleplay task (ex: shopping at the supermarket, ordering pizza, going to a pet shop) which fostered more spontaneous language use.

\section{Providing Scaffolds to Support Independent Learning Tasks and Learner Autonomy}

When teachers use literacy centres as a way to organize literacy instruction, they liberate themselves to work intensely with a few selected students, usually at a table in the back of the room. Teachers again questioned whether young language learners could perform L2 language tasks without the teacher being physically present in their learning. To counterbalance the need for teacher support at different literacy stations, mechanisms were developed to support beginning L2 students in accomplishing language/literacy tasks independently as they rotated through various literacy centres. Initially, it seemed easier for teachers to conceptualize ways of supporting L2 writing tasks (see Figures 6-8).

\section{Figure 6}

Writing Task - Example A

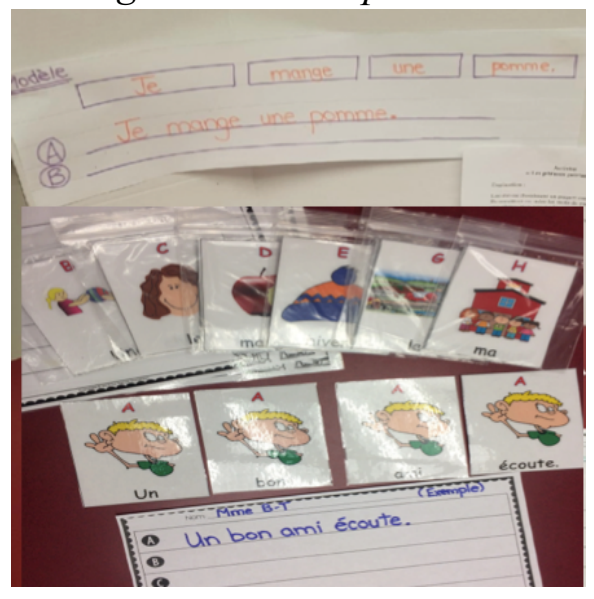

Canadian Journal of Applied Linguistics, Special Issue, 24, 2 (2021): 70-98 


\section{Figure 7}

Writing Task-Example B

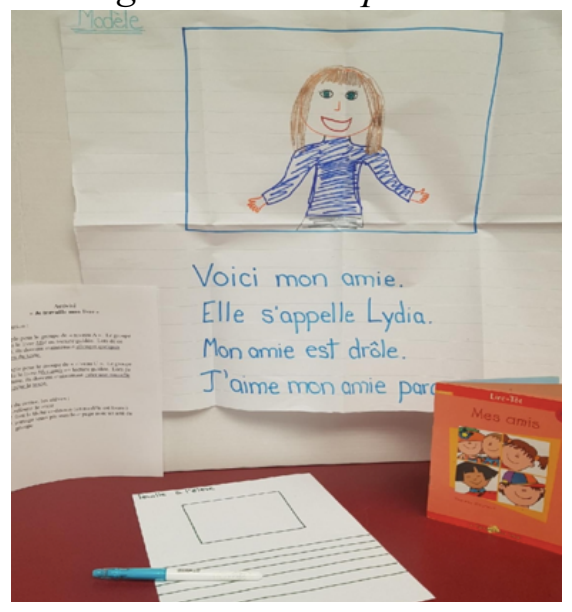

\section{Figure 8}

Writing Task-Example C

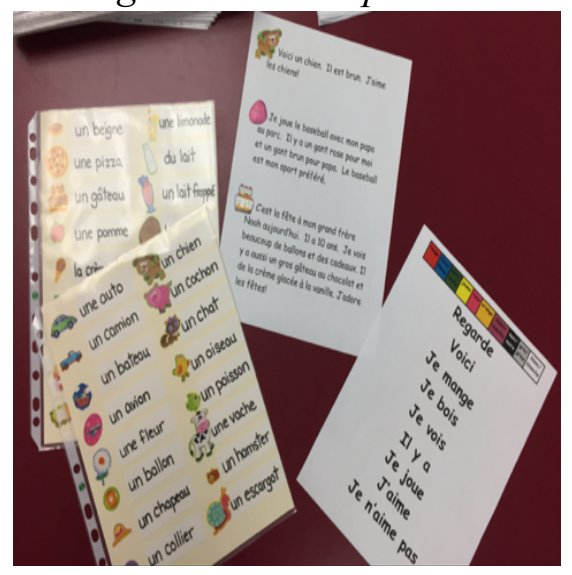

To support the L2 written communication tasks, teachers provided students with written exemplars of what the final writing product could look like. They were also provided with co-constructed teacher-student vocabulary lists, graphic organizers, sentence starters, and visuals. Such supports were found to help students produce L2 written language.

Researchers worked with teachers at identifying supports that could be used for oral communication tasks. In an effort to provide beginning L2 students with the linguistic scaffolds they needed, teachers created examples of scripts and dialogues for the different roleplay tasks (see Figure 9). They also provided students with vocabulary lists related to specific themes and offered sentence starters to support oral language output. 


\section{Figure 9}

Script for Ordering a Pizza

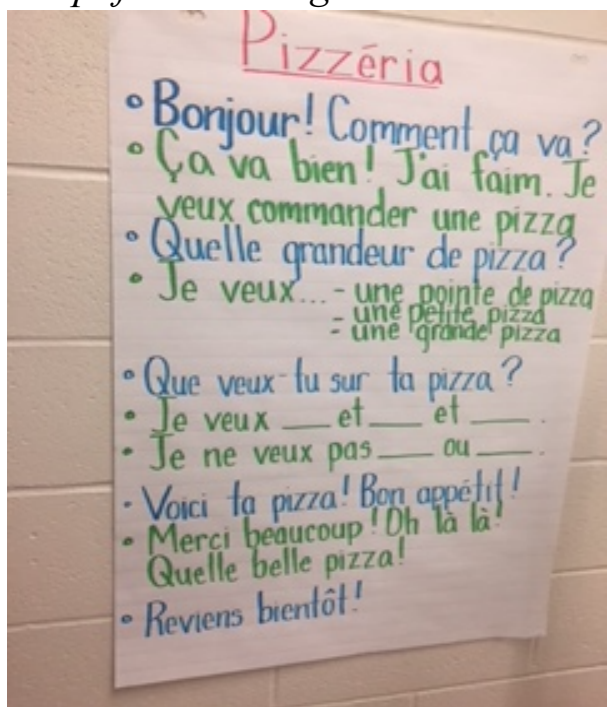

Figure 10

Connector Words Anchor Chart

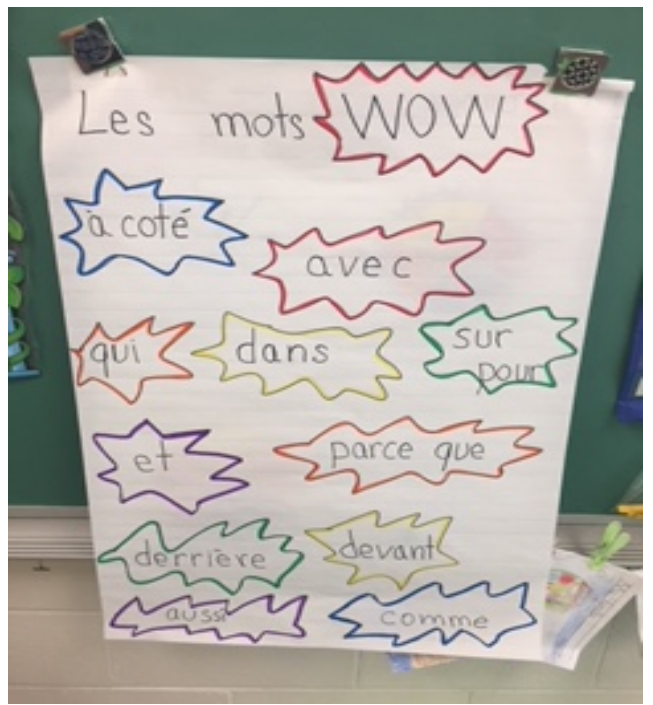

In addition to supporting general language output, scaffolds were also used to push students towards using increasingly more complex language forms and structures. For example, as students learned how to use adjectives when speaking and writing, the teacher would add a pre-taught adjective reference sheet to the centre to help reinforce their use during communicative tasks. Similar supports were used to help students use connector words in their oral speech and written work. Specifically, before students worked on the task of describing pictures, the teacher provided them with lessons on keywords (see Figure 7) to use to produce more complex sentences and vary the length of speech utterances. This visual aid was subsequently added to support independent learning at literacy stations (classroom observation data; teacher interviews). By offering such supports, data revealed that students produced work of higher quality and worked more 
autonomously. In the following exchange, during an oral communicative centre task (video recording transcription), students are describing photographs.

Fiona Je vois une fille avec un chandail rose $\underline{\text { et }}$ les pantalons bleu.

Jules Je vois beaucoup de feuilles de papier.

Mika Là?

Fiona $\quad$ Et les cheveux blonds.

Mika Je vois des ciseaux.

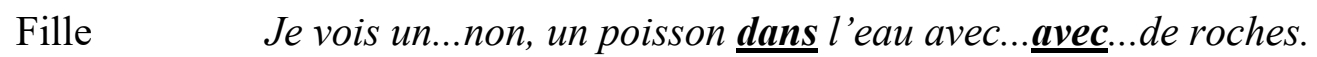

Gill Je vois des crayons $\underline{\boldsymbol{e t}}$...des crayons $\underline{\boldsymbol{e}}$ des ciseaux $\underline{\boldsymbol{e t}}$ des plantes.

Mika Je vois le poisson qui mange. Le poisson qui mange.

This example shows students reinforcing a newly acquired language concept (i.e., connector words) to producing more complex sentences and add more details to their speech. To produce this type of extended language output while also focusing on using connector words correctly (form), students referred back to and used the 'Connector words anchor chart' when at the learning centre (classroom observations). According to Missy, "Students had more confidence in using more complex sentence structures and even weaker students felt they could accomplish the task using the exemplars and visual aids" (teacher interview).

According to teacher interview data, students relied most heavily on scaffolds such as lexical frames, thematic word walls, sentence starters, and specific language structures to help them produce oral and written language earlier in the year. However, many students were able to move away from the provided scaffolds, especially when they became more comfortable at using the target language and were able to produce more spontaneous language. The following example, taken from classroom video recordings, demonstrates a move away from the provided oral script (see Figure 6) toward more spontaneous language production.

$\begin{array}{ll}\text { Julie } & \text { Bienvenue à Épicerie Davis. } \\ \text { Sammy } & \text { Bonjour, j'ai besoin de beaucoup de nourriture pour la maison. } \\ \text { Kris } & \text { Du brocoli ? } \\ \text { Samir } & \text { Je m'excuse on n'a pas du brocoli. } \\ \text { Julie } & \text { Du poulet? } \\ \text { Samir } & \text { Est-ce que tu veux trois poulets? } \\ \text { Sammy } & \text { Un poulet. } \\ \text { Samir } & \text { Je vais donner quel poulet } \text { ? Cette poulet ou cette poulet? }\end{array}$

According to the teachers, students no longer needed the scripts, not because they had memorized them, but because they were 'creating' and taking risks with the language to expand oral language output.

\section{Planning for the Interplay of Reading, Writing, and Oral Communication Skills}

An important element in the design of tasks for literacy centres was the need to respect the concept of balanced literacy by having listening, reading, writing, and oral 
communication skills working in concert with one another. Observational classroom data found that this could be done in different ways. In some cases, the teacher ensured that language objectives/features carried over from centre to centre, and from task to task. For example, students would work on the sentence structure 'Je vois...' at the writing centre and, as they moved to the reading centre, they were tasked with reading texts containing this structure. Finally, at the oral communication centre, they would practice this structure through oral communication tasks. Similarly, if students were working on transition words, tasks at the writing centre, reading centre, and oral communication centre would have a similar focus (classroom observational field notes).

In other cases, students worked on multiple language abilities simultaneously (ex: listening, reading, writing, oral communication) within a centre to support balanced literacy principles. For instance, the task at one station could include writing a few sentences, reading these sentences to a partner, and discussing with a partner how these sentences could be strengthened. In yet another example, students would use newly acquired vocabulary to create both oral and written sentences. Written sentences would then be read to a partner. In these examples, students worked on multiple language skills at any given station. Evidence of balanced literacy was also documented in how students applied and connected their learning from centre to centre. In these instances, work created at one centre was transferred to a different centre for additional use. For example, at the writing centre, students were given the task of writing down their shopping lists. They subsequently brought this list with them to the oral communication centre and used it as part of the roleplaying task. When rotating to the reading centre, they read their shopping lists to a partner (classroom observations).

Whether the connections among the different language abilities were created within a particular task or between learning stations, creating opportunities for students to share their ideas and discuss their work with others within their group fostered a greater sense of ownership over their language learning; encouraging the interplay of oral, reading and writing competences seemed to foster a greater need to communicate (Ellis, 2009). Work was also considered more meaningful as it was deemed important and perhaps even necessary for the completion of subsequent tasks.

\section{Moving from Whole Class Instruction to Small Group Learning}

Researchers worked with teachers in recognizing that centres ought to be conceptualized as opportunities to consolidate recent language/literacy learning. Before centre work could take place, whole group instruction of specific language and literacy outcomes took place. Teacher Missy explained that, before a task was brought into a literacy centre, it is first introduced during whole group instructional time. For example, if the literacy centre task called for students to read a passage and discuss its content with a partner, the teacher first taught students the strategies needed to read a text for comprehension and modelled how one goes about sharing the content of a text. And, if students were going to be asked to describe a picture or order a pizza at a learning centre, the teacher modelled how she completed a similar task. This whole group instruction was meant to "help learners effectively explore, internalize, and gain a greater understanding of the target language" (Bourke, 2008, p. 15). 
Guided instruction was also a part of whole group instruction. During guided practices, students worked on a task and received guidance and support from the teacher before attempting to do a similar task independently at their literacy stations. As Missy explained, "That way, we work on the vocabulary they need...it also gets them used to the task and the expectations...this [guided instruction] can last a week or two" (teacher interview). Whole group instruction of communicative and literacy tasks was deemed necessary because students were in Grade 1 and only at the beginning stages of learning French. As such, before specific language/literacy tasks could be completed independently by the students at centres, teachers provided explicit instruction of language features and structures, exposed students to required L2 vocabulary and modelled oral output expectations, grammatical points, and problem-solving strategies through teacher-students participation of similar tasks (classroom observational field notes). When teachers felt that students were ready to do similar tasks independently, they divided the class into smaller groups to perform similar tasks. This allowed students to experiment with the language, take risks, and problem solve when necessary. When the concept of centres was first introduced to the students, they worked on a very limited number of tasks. Slowly, as more whole-class instruction of tasks occurred, additional tasks/centres were added to the rotation.

\section{Using Visible Learning Techniques and Reinvesting Students' Work}

In an effort to ensure students remained actively engaged during independent learning tasks, the concept of visible learning was integrated into each task (Hattie, 2012). As teacher Missy explained, "I'm doing guided reading when students are at their centres and I can't circulate and see what they are doing" (teacher interview). This meant that, while working at language/literacy tasks at different learning stations, teachers planned for students to document their learning. Much care was taken in finding creative ways for beginning language learners to do so, given their age and linguistic abilities.

We didn't want students to document their learning simply through worksheets. Worksheets didn't work for certain tasks, including oral communication tasks. I wanted to hear what the students were producing when working together orally. It's important to find creative and engaging ways for them to show their learning...for motivation purposes. We needed to find multiple ways for students to represent and capture their learning. (Chrissy, teacher interview)

Students documented their learning in various ways including taking photographs of their work, videotaping/audiotaping themselves during oral communication tasks, drawing their understanding of comprehension tasks, filling in worksheets, providing writing samples, and doing self-evaluations. Teacher Missy explained that, as a result of these mechanisms, students took additional pride and ownership of their learning.

Students were really proud of themselves and the work they produced [during literacy centres]. They were proud of all the language they had acquired and always loved being given opportunities to show off their new talent. I found that audio or videotaping the tasks being performed at oral centres naturally 
encouraged and motivated students toward more spontaneous language use. (teacher interview)

Learning artifacts made tasks more visible and tangible for both teachers and students. It also ensured that independent language tasks were valued. "I really worked hard this year to value the work students did during literacy centres. I didn't do that before" (Missy, teacher interview).

An important finding of this study was the connection between students' proof of learning and the ways by which these were reinvested during focused whole group reinforcement lessons. As teacher Cara explained, "I hadn't thought about documenting students' learning of oral communication skills before, but this step is really important. For other tasks, it used to be worksheets, but students would put these in their binders, and we'd never look at it again" (Cara, teacher interview). Students' 'proofs of learning' became important pedagogical artifacts for teachers, not only to document students' learning but to help them build subsequent lessons, reflect on learning and plan the next step in their language learning. As teacher Chrissy explained:

Centre work usually lasts about 20 minutes. During this time, groups of students are assigned a particular centre. They go to their centre and work on a language/literacy task and document their learning. After 20 minutes or so, I bring the whole group back together and take this opportunity to revisit some of the work that was completed at different centres. I do this because it's important to value students' work, but I also do this because I can reinvest their learning. (teacher interview)

Teachers capitalized on this time to value students' work Students were eager to share their learning artifacts during the returns to whole group instruction. As teacher Cara stated, "They were really proud of themselves. [During focused whole group reinforcement lessons ] students would say things like I can do it! and Yah, I am able to do this! (teacher interview). Students felt that the work they had produced during various tasks was important and valued. On one occasion, for example, students could not wait to do the writing task because they wanted to share their work with the rest of their classmates (classroom observation).

Additionally, teachers found that the connection between students' proof of learning and the reinvestment of these learning artifacts during whole group lessons resulted in the following: an increase in participation and engagement during independently task work and higher quality of work produced by students. "Because we are revisiting students' work, they work harder on the tasks. In the beginning, I always had a few students who didn't do much at independent learning stations. Now, they are more interested and engaged" (Cara, teacher interview). These reinvestment opportunities also reinforce the importance of the teacher's role in TBLT in supporting language fluency and guiding students toward more precise language use. Whole group reinvestment of students' work was used to extend and build upon the learning, to focus on form, to encourage additional oral output and provide additional teaching. 
Teacher Owen, est-ce que tu veux que Madame montre ton dessin? On va parler de ton dessin? Ça va? Oui? Ok. Bon!... Qu'est-ce que tu vois dans le dessin? Lève la main.

John Ah, je vois des lapins.

Missy Comment est-ce qu'on peut encore plus étirer?

John Je vois deux lapins dans une cage.

Missy Une autre chose qu'on peut ajouter?...

Cayla Je vois un chat orange sur une étagère qui dort!

Teacher John, pourquoi est-ce que tu as colorié ceci comme tu l'as colorié?

John Ah, c'est parce que les poissons sont dans l'eau. (classroom

observation)

In the example above, the teacher used a student's artifact to stimulate a classroom discussion that focused on encouraging and supporting additional oral production. As Teacher Missy explained, "I would use the work students' did at independent literacy centres in future lessons...lessons following centre work or other lessons later in the week. I would use their work to a springboard to further develop the language, mostly to target vocabulary" (teacher interview).

By using students' learning artifacts, teachers were able to use whole group targeted lessons to recognize and celebrate students' strengths and reflect upon learning, but also allowed teachers to better identify students' linguistic needs. Classroom observation data revealed that teachers also used these focused whole group reinforcement lessons to do ongoing formative assessments, engage in corrective feedback techniques, and provide immediate feedback.

Teacher Qui peut me dire le mot pour les parties noires du chien. Comment s'appelle ... on a appris ce mot. Felix?

Felix Pattes

Teacher Ok, il a des pattes noires. Ok. Je donne ça, mais je cherche un autre mot pour les petites parties partout sur son corps. Julie?

Julie Rayures?

Teacher Rayures, ça c'est comme un tigre. Un tigre a des rayures.

The teacher recognized that students were not using the right word. As such, she took this opportunity to review vocabulary to ensure students' understanding of different words. Because independent language/literacy tasks were designed with specific outcomes in mind, teachers were able to conduct comprehension checks and monitor students' progress during these reinvestment opportunities. It provided teachers with a context to assess students' work in real-time and provide immediate feedback to students. As Missy explained, "It allows me to encourage students, but also provide some feedback and suggestions, but also do fix mistakes and provide corrections (teacher interview). Teachers were able to use the information they gathered during these reinforcement lessons to modify tasks and ensure students were working on increasingly more complex language/literacy skills. 


\section{Discussion}

There have been calls for additional classroom-based TBLT research (Bygate, 2016) as

little research has been conducted with young elementary L2 students. To help fill this existing gap in the literature, this study sought to document the results of implementing TBLT principles with beginning language learners in early FI classrooms. Independent learning stations are a popular classroom organizational structure used in elementary FI classrooms. However, questions remained on how to ensure that language/literacy tasks proposed at these independent learning stations are effective in supporting the unique learning needs of beginning language learners.

Researchers and teachers were particularly interested in the first research question which explored how aspects of TBLT could be applied or adapted to account for students' age, their oral language abilities, and the fact that tasks were to be conducted in a classroom setting without the direct support of teachers. In considering the findings related to this research question, we offer the following adaptations:

1. Orienting instruction toward function, without negating the importance of form, coupled with the use of clearly defined language/learning objective, articulated to students using 'I can' statements (Bruton, 2005). This aspect of TBLT allows for more student ownership over learning. Effective classroom-based language tasks should have clearly defined objectives even when students are expected to complete them independently.

2. Integrating more communicative tasks (related to real-life tasks) within the literacy centre framework, which tend to focus more on developing reading and writing skills. Even young beginning language students are able to complete communicative tasks independently in their L2 with proper instruction and scaffolds. Given the age of the students and the context within which they are learning the L2, real-life activities/tasks should include symbolic play, social interactions and inquiries that help them learn about the world they live in, and classroom learning activities designed to help them learn how to read, write and communicate.

3. Providing scaffolds to support oral communication tasks, reading tasks and writing tasks to increase learner autonomy and language/literacy output. Scaffolds can help counteract the need for continuous, direct teacher support when working independently on language/literacy tasks

4. Modifying language/literacy tasks, as needed, in light of students' increasing language abilities. Considerations for the need to continue designing tasks that provide enough of an information gap to foster risk-taking and extended output. Tasks designed to fill an information gap allow students to work through language learning in new, creative, and spontaneous ways (Ellis, 2009).

5. Ensuring the development of oral, reading, and writing within different tasks to adhere to balanced literacy principles. This ensures instruction of all aspects of L2 literacy acquisition and can help foster a need to communicate in the L2.

6. Recognizing that independent learning centres are reinforcement learning opportunities to learning taking place during whole group instruction; the role of 
the Gradual Release of Responsibility Model (Webb et al., 2019) cannot be ignored when using literacy centres. Reinforcement learning centres provide opportunities for students to work on tasks that enable them to experiment with the L2 language, take risks, and problem solve when needed.

7. Valuing students' task-based learning through the use of visible learning strategies (Hattie, 2012) and large group reinvestment lessons. Reinvestment lessons serve to reinforce language structures and features, to notice errors, to reflect on learning, to problem solve, and determine next steps. They also allow students to observe their own language use and make hypotheses about their language learning (Ellis, 2009).

These characteristics, working in concert with each other, led to the examination of our second research question: How do these tasks favour language/literacy acquisition and extended language/literacy learning for young beginning language learners? The results of our initial research question revealed that the aforementioned principles or aspects of TBLT were particularly impactful in supporting language/literacy acquisition, extended language output, peer interaction, learner autonomy, student engagement, and use of corrective feedback in immersion classrooms.

Clearly defined learning/language outcomes helped teachers create purposeful and structured tasks designed to maximize student learning. The shift from using literacy centres as solely an organizational framework to carefully planned opportunities to participate in language/literacy tasks was impactful. Identifying clear literacy objectives for centres seemed to reorient teachers' focus on more language output tasks. In L1 contexts, literacy centres favour reading and writing tasks over communicative ones. With an increased focus on oral communication skills within literacy centres, we witnessed the emergence of language learning centres. Initially, students were not associating literacy stations with a need to speak in the target language because tasks had not been designed to foster interactions among students, nor had they been created to fill a language gap or need. When tasked were redesigned with this in mind and language output expectations were shared with students, they began to see literacy centres as a time to practice speaking in French.

With time, oral language tasks became increasingly more meaningful and life-like for students (i.e., making shopping lists and role-playing going to the store, role-playing a visit to a pet shop), thus eliminating the sentiment of 'busy work'. Teachers were able to create, within these independent learning tasks, a renewed need to communicate in French (function). The importance of this finding has also been reported elsewhere (Ellis, 2000, 2003, 2017; Skehan, 1998; Nunan, 2006). In addition to a focus on function, targeted language/literacy outcomes also meant a renewed focus on teaching specific linguistic features and forms. These life-like language-related tasks seemed to increase students' confidence and foster more risk-taking with language. It also allowed for opportunities to negotiate meaning and produce extended language output.

Teachers reported that the authentic nature of the tasks also strengthened student engagement. The importance of task authenticity - in primary education settings, represented in symbolic play - was strongly reflected in the data. As such, the authors intend to specifically address these findings in a future article. The use of 'I can...' statements played an important role in the development of more autonomous L2 learners (Little, 2007) and help empower students to take more ownership for their language 
learning, both during the task and after, during whole-class reinvestment opportunities. Since language/literacy outcomes had been clearly articulated and modelled for students during whole group instructional lessons, students better understood the language expectations required for the tasks assigned to them during centre work. These 'I can...' statements positioned literacy centres as spaces of learning and allowed for students to work more independently.

Tasks performed at various literacy centres became better connected to whole class learning goals and we observed the emergence of a task-based language and learning cycle. In addition to planning for and proposing tasks to students that respected the characteristics described here, teachers followed a highly structured instructional delivery model in which responsibility for learning was gradually transferred to students (Webb et al., 2019). Some language awareness and task-based literature highlight the need for a task cycle that can include enabling tasks, which "provide students with the necessary linguistic tools to carry out a communication task" (Estaire \& Zanon, 1994, p. 15), followed by communicative tasks, and analysis or practice activities (Bourke, 2008).

Instruction done prior to centre/station work provided teachers with opportunities to focus on form (language accuracy/precision), to teach and model specific linguistic features, and incite students in guided practice before they work independently on language/literacy tasks. After the completion tasks, teachers carved out opportunities to revisit the learning that took place during these independent tasks to allow students to reflect on their language use, to help students self-correct, and review/teach additional elements of the language when necessary.

Valuing students' task-based learning through the use of visible learning strategies was important in documenting students' learning during centre work. It became an important element in helping teachers and students revisit and take stock of their language use. Subsequent large group reinvestment lessons helped teachers assess, on an ongoing basis, the development of students' language/literacy skills and abilities (Ellis et al., 2019). Teachers were able to adjust and modify independent learning tasks accordingly. Evidence from data collected demonstrated that teachers became increasingly more adept at designed tasks that were linguistically appropriate for beginning language learners. Students in this study were both young ( 5 and 6 years old) and new to L2 learning. As a result, it seemed important to start with more language-controlled language/literacy tasks in hope of extended output and limiting the use of the L1. Data indicate that students' successful completion of language-related tasks was positively influencing their confidence level while also encouraging increased risk-taking and use of the L2. When designing tasks, teachers considered how quickly students moved through different language acquisition phases and accounted for the increasing need to support more spontaneous oral communication opportunities. This ensured that output demands continued to increase as students developed additional language skills throughout the year. Additionally, what constituted comprehensible input fluctuated throughout the year and, as such, what students read and listen to during literacy centres remained important considerations. On a cognitive level, however, tasks proposed to students throughout the year seemed to remain appropriate for Grade 1 students.

The subsequent reinvestment of students learning, using learning artifacts, during large group reinvestment lessons created an interesting layer to a needs-based approach to language learning (Nunan, 2006). Whole group reinvestments enabled teachers to shift 
their instruction toward language precision (focus on form) and helped complete the task cycle (Bourke, 2008). Assessment for learning was at the heart of this process. Whole group reinvestment lessons allowed teachers to determine when students were ready to become more autonomous with particular L2 language/literacy tasks. Students were engaged in reflecting on their own language learning and in determining next steps. Teachers also capitalized on students' learning artifacts, produced during different independent learning tasks, by providing corrective feedback (Ranta \& Lyster, 2018) and pushing students' language output.

Scaffolded instruction of tasks was important if teachers were to strike a balance between L2 learner autonomy and the need to support the linguistic demands of beginning L2 language learners. Achieving this balance needs careful considerations because learning scaffolds could not be withdrawn too quickly, given students' age and language abilities. It would appear that beginning L2 language learners are able to participate fully in L2 language/literacy tasks when performed at independent learning stations if appropriate and adequate scaffolds are in place and the tasks are adapted to the needs of young L2 learners.

The use of the Gradual Release of Responsibility Model, coupled with an increased number of scaffolds in various literacy centres, appeared to have contributed to strengthening students' literacy skills. Scaffolds not only contributed to students' increased confidence and language output but helped students negotiate the need for both meaning and form (Tedick \& Lyster, 2019). When working in these small group collaborative stations on L2 language-related tasks, students used linguistic supports to negotiate meaning, monitor their comprehension, and ask for help. Data revealed, however, that supports for oral communication tasks were somewhat more limited than those provided to support written tasks. Scaffolds for oral communication tasks tended to be in the form of vocabulary lists and sentence starters (ex: Je vois...; Il y a ....). The use of pre-recorded oral explanations or pre-recorded exemplars demonstrating output demands, for example, could be explored further. Students' self-recordings during the completion of tasks could also be explored further as ways for assessing and reinvesting language learning.

The findings of our first two research questions enabled us to explore our third research question, that of identifying instructional structures and strategies needed to effectively implement/adapt TBLT principles in classrooms where beginning L2 students are expected to work independently on second language/literacy skills at small group learning stations. In light of our findings and in alignment with our research methodology of theorizing within actual classroom contexts, of developing materials and strategies that affect pedagogical practice and being product-oriented, we devised a few instructional recommendations for teachers' consideration.

Recommendation 1: Ask students to share what is meaningful to them and what types of tasks they engage in at home and in their community (i.e., playing with stuffed animals, shopping for a toy, making ice cream sundaes, playing to the playground, writing secret messages to a friend, being read to by a parent). Use students' experiences as inspiration when creating L2 'life-like oral communication and literacy tasks.

Recommendation 2: Write down and post 'clearly defined outcomes' for each language/literacy station. These 'I can' statements should be written in plain, studentfriendly language. The use of visual supports to facilitate comprehension of these learning outcomes is encouraged for beginning language learners. 


\section{Figure 11}

Examples of 'I can' Statements for Beginning Language Learners
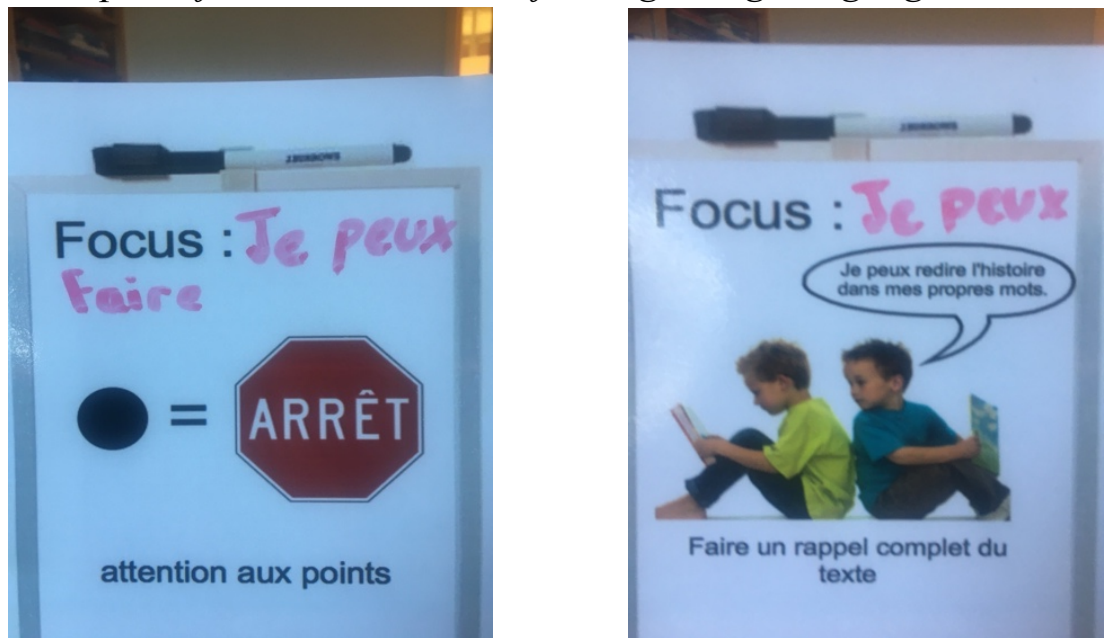

Recommendation 3: Model, during whole class instruction, the use of oral language functions and structures. To support this instruction, create and post, around the room, anchor charts and other supports that students can refer to when asked to produce oral language independently.

\section{Figure 12}

Examples of Anchor Charts to Support Oral Language Output
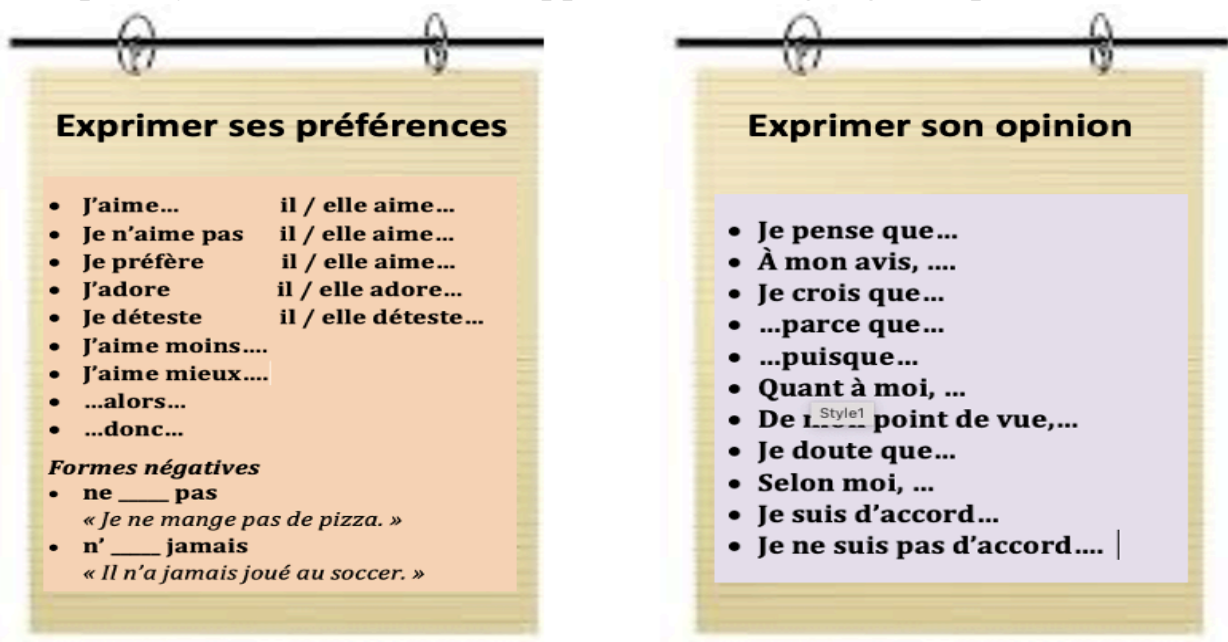

We tend to offer more supports and resources for written tasks than oral tasks. Consider the tools students need to support oral production tasks.

Recommendation 4: Consider differentiation strategies when planning a new task to be completed at a literacy centre. Ask yourself the following questions: How can I make this language/literacy task more complex for some students? How can I simplify this task to ensure that the following students can complete the task?

Recommendation 5: Do not rush the time you use to reinvest students' learning. Whole group reinvestment opportunities are crucial to expand upon the teaching and learning of language/literacy skills. Consider them not only as occasions to celebrate students' work 
but more importantly teaching opportunities. Students' work can be used reinvested as whole group mini-lessons or can be used as springboards to future lessons.

\section{Conclusion}

In elementary FI classrooms, when comprehensible input and frequent opportunities for extended production are particularly crucial, many teachers use L1 literacy pedagogies. By using literacy centres are an instruction framework, students are expected to work autonomously for extended periods of time while the teacher provides remedial supports to a few selected students. To ensure meaningful learning within L2 classroom contexts using this approach, there is a need to study the role TBLT principles can play in helping young language learners develop their L2. The findings of this study indicate that beginner language learners are able to interact independently in their L2 when accomplishing tasks at literacy centres if tasks adhere to TBLT principles and consider the unique needs of L2 learners. Additionally, emerging from this study are interesting suggestions about the importance of symbolic play in task-based learning for young elementary students. The authors plan to explore this finding further in subsequent articles. Possible limitations of this study include the smaller number of participants and the need to re-examine these findings with more advanced language learners in FI. Questions remain with respect to how better develop communicative and literacy tasks with L2 students at other grade levels that investigate the implementation of TBLT in such real-life classroom teaching and learning contexts.

To our knowledge, no other study in the Canadian FI context, except Pellerin (2014), has reported on TBLT for young language learners. Our study provides an important contribution to the field as we were able to report on the outcomes of applying TBLT principles in classroom environments where young learners are in the beginning stages of L2 acquisition. Through the use of a research paradigm in education of developing pedagogical materials, strategies, and methods that affects pedagogical practice, we were able to connect research and practice in order to theorize within actual classroom contexts. As a result, we were able to shed light into ways TBLT principles can be applied to classroom language learning contexts to support L2 language learners.

Correspondence should be addressed to Renée Bourgoin.

Email: rbourgoin@stu.ca

\section{References}

Alberta Education. (2015). What is literacy? Retrieved from https://education.alberta.ca/literacy-and-numeracy/literacy/everyone/what-isliteracy/

Barab, S. \& Squire, K. (2004). Design-based research: Putting a stake in the ground. Journal of the Learning Sciences, 13(1), 1-14.

Bourgoin, R. \& Le Bouthillier, J. (2021). Task-Based Language Teaching and Beginning Language Learners: Lessons From Class-Based research Examining Small Group Learning Contexts. Conference presentation. American Association of Applied Linguistics. 
Bourke, J. (2008). A Rough Guide to Language Awareness. English Teaching Forum, 46 (1), 12-21.

Brown, A. (1992). Design experiments: Theoretical and methodological challenges in creating complex interventions in classroom settings. The Journal of the Learning Sciences, 2(2), 141-178.

Bruton, A. (2005). Task Based Language Teaching: For the state secondary FL classroom? Language Learning Journal, 31, 55-68.

Bygate, M. (2016). Sources, developments and directions of task-based language teaching, The Language Learning Journal, 44(4), 381-400.

Cambourne, B. (2001). What do I do with the rest of the class?: The nature of teachinglearning activities. Language Arts, 79(2), 124-135.

Canadian Association of Immersion Professionals. (2018). Rapport final : Consultation pancanadienne. Journal de l'immersion, 40(2).

Carless, D. (2004). Issues in teacher's reinterpretation of a task-based innovation in primary schools. TESOL Quartely, 38(4), 639-662.

Cobb, P., Confrey, J., diSessa, A., Lehrer, R. \& Schauble, L. (2003). Design experiments in educational research. Educational Researcher, 32(1), 9-13.

DeKeyser, R. (2018). Task repetition for language: A perspective from skill acquisition. In Bygate, M. (p. 27-41). Learning Language Through Task Repetition. John Benjamins Publishing Company.

Diller, D. (2010). Les centres de littératie. Chenelière Éducation.

Diller, D. (2005). Practice With Purpose. Literacy Work Stations for Grades 1-3. Stenhouse Publishers.

Ellis, R. (2000). Task-based research and language pedagogy. Language Teaching Research, 4, 193-220

Ellis, R. (2003). Task-based language teaching. Oxford University Press.

Ellis, R. (2009). Task-based language teaching: Sorting out the misunderstandings. International Journal of Applied Linguistics, 19(3), 221-246.

Ellis, R. (2017). Moving task-based language teaching forward. Language Teaching, 50(4), 441-482

Ellis, R., Skehan, P., Li, S., Shintani, N., Lambert, C. (2019). Task-Based Language Teaching Theory and Practice. Cambridge Applied Linguistics.

Estaire, S., and J. Zanon. (1994). Planning classwork: A task-based approach. Macmillan Heinemann.

Falk-Ross, F. (2008). Helping Literacy Centres Come Alive for Teachers. In Foote, M., Szabo, S., Falk-Ross, F. \& Sampson, M.B. (Eds.). Navigating the Literacy Waters: Research, Praxis, and Advocacy. (pp. 238-246). College Reading Association.

Ford, M. \& Opitz, M. (2002). Using Centres to Engage Children during Guided Reading Time: Intensifying Learning Experiences Away from the Teacher. The Reading Teacher, 55(8), 710-717.

Fountas, I. \& Pinnell, G.S. Guided reading. Responsive Teaching Across the Grades (2 $2^{\text {nd }}$ ed.). Heinemann.

Hattie, J. (2012). Visible Learning for teacher: Maximizing impact on Learning. Routledge. 
Kemmis, S. and McTaggart, R. (2005). Participatory action research: Communicative action and the public sphere. In Denzin, N.K. and Lincoln, Y.S. (eds), The Sage handbook of qualitative research (p.559-602). Sage Publications Ltd.

Kim, S. (2013). Comparison of task-based and storytelling-based English classroom interaction in Korean elementary schools. English Teaching, 68(3), 51- 83.

Kracl, C. (2012). Using literacy stations to manage small group instruction. International Journal of Humanities and Social Science, 2(18), 200-209.

Kucer, S. (2015). Literacy: Varied, Dynamic, and Multidimensional. Journal of Family Strengths. 15(2). https://digitalcommons.library.tmc.edu/jfs/vol15/iss2/1

Lee, S.-M. (2005). The pros and cons of task-based instruction in elementary English classes. English Teaching, 60(2), 185-205.

Little, D. (2007). Language Learner Autonomy: Some Fundamental Considerations Revisited, Innovation. Language Learning and Teaching, 1(1), 1429, https://doi.org/10.2167/illt040.0

Loiselle, J. \& Harvey, S. (2007). La recherche développement en éducation : Fondements, apports et limites. Recherches qualitatives, 27(1), 40-59.

Long, M. H. (1996). The role of the linguistic environment in second language acquisition. In W. C. Ritchie \& T. K. Bhatia (Eds.). Handbook of language acquisition: Second language acquisition (pp. 413-468). Academic.

Newton, J. \& Bui, T. (2018). Teaching with tasks in primary school EFL classrooms in Vietnam. Dans M. Ahmadian \& M. García Mayo (Dirs.). Recent Perspectives on Task-Based Language Learning and Teaching. (259-278). De Gruyter Mouton.

Nunan, D. (2006). Task-based Language Teaching in the Asia Context: Defining 'Task'. Asian EFL Journal, 8(3), 12-18.

Ontario's Ministry of Education (2013). Paying Attention to Literacy K-12. Queen's Printer for Ontario.

Literacy for Learning: The Report of the Expert Panel on Literacy in Grades 4-6 in Ontario. Government of Ontario.

Oxford, R. (2006). Task-Based Language Teaching and Learning: An Overview. Asian EFL Journal, 8(3), 94-121.

Pellerin, M. (2014). Language Tasks and Mobile Technologies: A Paradigm Shift in Designing Task-Based CALL for Young Language Learners. Canadian Journal of Learning and Technology. 40(1). https://doi.org/10.21432/T2K01N

Ranta, L. \& Lyster, R. (2018). Form-focused Instruction. In Garrett, P. \& Cots, J. (Eds.) The Routledge Handbook of Language Awaress, (pp. 58-74). Routledge

Reutzel, R.D. \& Clark, S. (2011). Organizing Literacy Classrooms For effective Instruction. The Reading Teacher, 65(2), 96-109.

Shanahan, T. (2016). Relationships between Reading and Writing Development. In C. MacArthur, S. Graham \& J. Fitzgerald (Eds.) Handbook of Writing Research, $\left(2^{\text {nd }}\right.$ Edition, p. 194-207). Guilford Press.

Shehadeh, A. (2012). Broadening the perspective of tasks-based language teaching scholarship: The contribution of research in foreign language contexts. In Shehadeh, A \& Coombe, C. A. (Eds.). (pp. 1-20). Task-based language teaching in foreign language contexts:Research and implementation. John Benjamin.

Skehan, P. (1998). A cognitive approach to language learning. Oxford University Press. 
Soucy, E. (2016). Quelle place pour l'oral dans les centres de littératie? Language and Literacy, 18(2), 1-16.

Stout, R. (2009). Putting Literacy Centres to Work : A Novice Teacher Utilizes Literacy Centres to Improve Reading Instruction. Networks, 11(1).

Street, B. \& Lefstein, A. (2007). Literacy. Routledge.

Tedick, D. \& Lyster, R. (2019). Scaffolding Language Development in Immersion and Dual Language Classrooms. Routledge

Webb, S., Massey, D., Goggans, M. \& Flajole, K. (2019). Thirty-Five Years of the Gradual Release of Responsibility: Scaffolding Toward Complex and Responsive Teaching. The Reading Teacher, 73(1), 75-83 https://ila.onlinelibrary.wiley.com/doi/full/10.1002/trtr.1799

Worthy, B., Pursley, B., Hungerford-Kresser, H., Hampton, A., Jordan, M. \& Semingson, P. (2015). What are the rest of the students doing? Literacy work stations in two first-grade classrooms. Language Arts, 92(3), 173-186. 